\title{
GROWTH OF LETTUCE AND WATER SPINACH IN SILVER CATFISH (Pangasius Sp) CULTURE USING AQUAPONIC SYSTEM
}

\section{PERTUMBUHAN TANAMAN SELADA DAN KANGKUNG DALAM BUDIDAYA IKAN PATIN (Pangasius sp) PADA SISTEM AKUAPONIK}

\author{
Yuli Andriani*, Zahidah, Yayat Dhahiyat, Herman Hamdani, Ristiana Dewi. \\ Fisheries Study Program, Faculty of Fisheries and Marine Sciences, Universitas Padjadjaran \\ Jln. Raya Bandung Sumedang KM 21, Jatinangor 40600 \\ *Correspondence: yuli.andriani@unpad.ac.id
}

Accepted : $10^{\text {th }}$ Juny $2020 /$ Approved: $28^{\text {th }}$ Novembe 2020

\begin{abstract}
Solid and liquid wastes from feces and fish feed residues can affect water quality, which in turn affect fish physiological processes, behavior, growth and mortality. So it is necessary to have water quality management in the aquaponic system. This study aimed to observe the growth of lettuce and water spinach as biofilters in silver catfish culture (Pangasius $\mathrm{sp}$ ) using aquaponic system. The study was conducted at the Laboratory of Fisheries, Faculty of Fisheries and Marine Sciences, Universitas Padjadjaran, from March to April 2018. This was an experimental study using Randomized Block Design (RBD) with two treatments and six repetitions to compare between combination of silver catfish and water spinach with silver catfish and lettuce combination. The parameters observed were fish growth, fish survival, increase in stem length, and increase in the number of leaves. The results show silver catfish and water spinach combination produced the highest crop with a stem length of $38.7 \mathrm{~cm}$ and more leaves with an addition of 16 leaves. A higher absolute growth of 7.79 grams fish $^{-1}$ and $100 \%$ survival are also seen in this combination. Furthermore, water spinach is more effective as biofilter for aquaponic systems than lettuce.
\end{abstract}

Keywords: Aquaponics, Biofilter, Lettuce, Silver catfish, Water spinach

\section{ABSTRAK}

Limbah padat dan cair dari feses dan sisa pakan ikan dapat mempengaruhi kualitas air, yang selanjutnya memengaruhi proses fisiologis ikan, perilaku, pertumbuhan, dan angka kematian. Sehingga perlu adanya manajemen kualitas air pada sistem akuaponik. Penelitian ini bertujuan untuk mengamati pertumbuhan selada dan kangkung sebagai biofilter pada budidaya ikan lele (Pangasius sp) dengan sistem aquaponik. Penelitian dilaksanakan di Laboratorium Perikanan, Fakultas Perikanan dan IImu Kelautan Universitas Padjadjaran dari bulan Maret hingga April 2018. Penelitian ini merupakan penelitian eksperimental dengan menggunakan Rancangan Acak Kelompok (RAK) dengan dua perlakuan dan enam ulangan untuk membandingkan kombinasi Ikan Patin dan kangkung dengan kombinasi lele dan selada. Parameter yang diamati adalah pertumbuhan ikan, kelangsungan hidup ikan, pertambahan panjang batang, dan pertambahan jumlah daun. Hasil penelitian menunjukkan Kombinasi lele perak dan kangkung menghasilkan spinach growth in silver catfish (Pangasius Sp) culture using aquaponic system. Jurnal Agro, 7(2), 148-157. https://doi.org/10.15575/8724 
tanaman tertinggi dengan panjang batang 38,7 dan daun lebih banyak dengan penambahan 16 helai daun. Pertumbuhan absolut yang lebih tinggi sebesar $7,79 \mathrm{~g} \mathrm{ikan}^{-1}$ dan kelangsungan hidup $100 \%$ juga terlihat pada kombinasi ini. Dengan demikan kangkung merupakan biofilter yang lebih efektif untuk aquaponik dibandingkan selada.

Kata Kunci : Aquaponik, Biofilter, Ikan patin, Kangkung, Selada

\section{INTRODUCTION}

Solid and liquid waste from feces and fish feed residues are inevitable in cultivation activities. Unfortunately, these wastes can accummulate and decrease water quality, which then affect the fish physiological processes, behavior, growth, and mortality rate. Therefore, management of water quality is needed for fish culture media (Kamauddin et al., 2019).

Aquaponics is an integrated aquaculture and hydroponic system for fish and plant cultivation. The interaction between fish and crops produces an ideal environment for growth, making it more productive than conventional methods (Yep \& Zheng, 2019). Aquaponics system uses crop cultivation to reduce organic materials by absorbing wastewater. Crops in hydroponic systems are grown with roots submerged in water and function as a biofilter to degrade toxic substances into safe substances for fish while supplying oxygen to the water that is used for fish maintenance (Wongkiew et al., 2017).

The frequently used vegetable crops in aquaponics systems include lettuce (Lactuca sativa L.) and water spinach (Ipomoea reptans P.). Lettuce is widely used in these systems, because it grows quickly and does not have as many pest-related problems as fruiting crops (Rokhmah et al., 2014; Abbey et al., 2019). Water spinach is a fast-growing crop with weaker thick fibrous roots and requires continuous availability of water (Andriani et al., 2019).
The different types of crops used in aquaponics system lead to different organic matter uptakes; however, the use of both types of crops in aquaponics systems will reduce organic materials. The silver catfish was selected to assess the growth response of the two types of crops in aquaponics system in this study because silver catfish is a fish that has economic values and the use of this fish in this system will create interests among fish farmers because it enables them to increase production through intensive cultivation. Silver catfish have many advantages when compared to other freshwater fish. Its meat has a fairly high calorie and protein contents with distinctive, tasty, delicious, and savory taste, making it popular with the community. Silver catfish is also considered healthier when compared to other livestock meats due to its low cholesterol level. There are also other advantages, such as the large size of the individual fish that can reach 120 $\mathrm{cm}$ long in nature (Thong et al., 2020). Exporters have also declared their ability to accommodate pangasius produced in seven provinces of Indonesia to be exported to the United States and European countries (Ramadhan et al., 2016).

This study aimed to determine the effectiveness of lettuce and water spinach crops as biofilters in aquaponics systems with catfish. 


\section{MATERIALS AND METHODS}

This study was performed during the period of March to April 2018 at the Fisheries Laboratory, Faculty of Fisheries and Marine Science, Universitas Padjadjaran while the water quality test was carried out at the Ecology Laboratory, Center for Research and Development of Natural Resources and Environment (Pusat Penelitian dan Pengembangan Sumber Daya Alam dan Lingkungan, PPSDAL) of Universitas Padjadjaran. Vegetables used were 1-2 weeks old lettuce and water spinach obtained from seeding using rockwool, silver catfish used was $3-7 \mathrm{~cm}$ in size, two fiber water containers with a diameter of $30 \mathrm{~cm}$ and $100 \mathrm{~cm}$ deep, 90 watt $(4 \mathrm{~m})$ and a 25 watt $(2 \mathrm{~m})$ pumps, heater, plastic cups were used for the crops, and digital scale.

\section{STATISTICAL DESIGN}

This was an experimental study using two types of crops (lettuce and water spinach) and silver catfish in aquaponic system. Randomized Block Design (RBD) with two treatments ( $A$ : lettuce and silver catfish and $B$ : water spinach and silver catfish) with six repetitions for each treatment.

\section{Procedures}

Fish acclimatization was performed to give the opportunity to the fish to adapt to the new environment and to make sure that fish were already well-adapted to the environment when the study process took place. The newly purchased fish were kept in an acclimatization container (fiber container) for 1 week to eliminate stress and reduce mortality rate. Feed was given ad libitum on a regular basis two times a day (8:00 a.m. and 8:00 p.m.) to ensure that the fish received food intake continuously during the adaptation process.

A recirculated aquaponics system, i.e. water in the fish maintenance container of fish was distributed into the crop container which was installed separately using a 4" PVC pipe 4 "and placed on a 4-storey iron shelf, was installed. One of the ends of the $4 "$ PVC pipe on the top level rack was hollowed out and connected to the $1 / 2$ " PVC pipe that was attached to the water pump that drew the water to be distributed to the crop container above. Under the drain pipe, a small container was placed as water reservoir. The water in the reservoir container was flowed back through the $1 / 2 "$ PVC pipe using a water pump to send it back to the container where the fish were kept. The process of crop seeding was carried out by croping lettuce and water spinach seeds in net pots using soil and rockwool. Lettuce and water spinach were sown for 2 weeks before croping them in the growing media of the aquaponics media.

The main study was conducted for 30 days. The density of silver catfish was 354 fish per fiber. Ad libitum feeding was performed twice a day at 07.00 and 15.00 Western Indonesian Time. Died fish was counted every day and the weight and length of the fish were measured once a week in $30 \%$ of the total number of test fish. The observation of crops was performed once a week through. Parameters observed were fish growth, fish survival, plant stem length, and plant leaves number were.

\section{Fish Growth}

The weight and length were measured in sample fish. The calculation of the absolute growth and growth rate were done using the formula below (Ogunji et al., 2008): 
a. Absolute Growth

$A G=W t-W_{0}$

b. Spesific Growth Rate

$S G R=(\operatorname{Ln} W t-\operatorname{Ln} W o): T \times 100 \%$

Notes:

SGR = Specific growth rate (\%)

Wo = Initial fish weight $(\mathrm{g})$

$\mathrm{Wt} \quad=$ Final fish weight $(\mathrm{g})$

$\mathrm{T} \quad=$ Number of days during maintenance (days)

\section{Survival}

Fish survival was calculated using the following formula (Effendie, 1979):

$\mathrm{SR}=\mathrm{Nt} / \mathrm{No} \times 100 \%$

Notes:

SR = Survival Rate (100\%).

$\mathrm{Nt} \quad=$ Final number of test fish

No $=$ Initial number of test fish

The length of crop stem measurement and calculation of the addition of leaves were performed regularly every seven days from the beginning until the last day of the observation in this study.

\section{DATA ANALYSIS}

Descriptive analysis through observational analysis of supporting data and related literatures was performed on the data, followed by the analysis of variance (F-test) at $95 \%$ confidence level to determine the effect of each treatment on the plant stem length and the addition of leaves. When a significant difference between the treatments was found, the Duncan multiple distance test with $\alpha=5 \%$ was performed (Gaspersz, 1995).

\section{RESULTS AND DISCUSSION}

\section{Fish Growth}

At the beginning of the stocking, the average weight of the Dry weight of the silver catfish was $3.55 \mathrm{~g}_{\text {fish }}{ }^{-1}$. After 30 days of maintenance, the final weight of silver catfish was $11.34 \mathrm{~g} \mathrm{fish}^{-1}$ and $13.22 \mathrm{~g} \mathrm{fish}^{-1}$ (Figure 1).

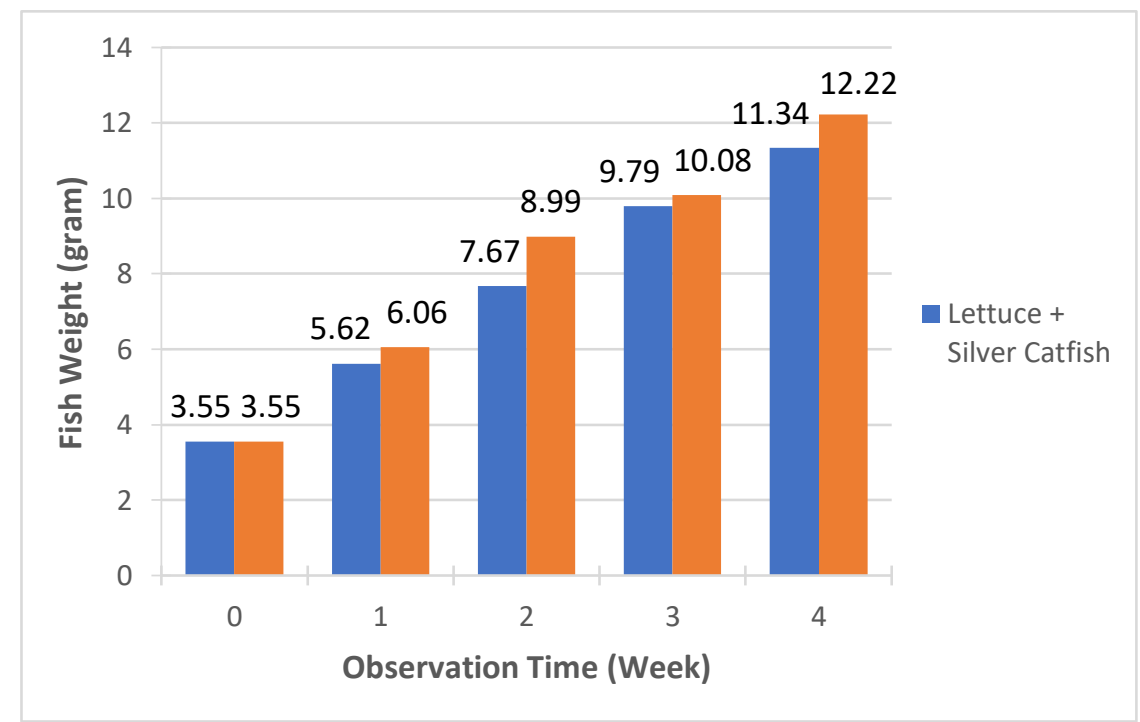

Figure 1. Silver Catfish Average Weight Gain 
The growth of silver catfish was different when combined with different crops (Table 1). The silver catfish absolute growth and growth rate, when combined with water spinach were higher but not significantly different.

The growth of silver catfish was different when combined with different crops (Table 1). The results showed that absolute growth and the growth rate of silver catfish combined with water spinach had a higher value but not significantly different. The unsignificant differences fish growth in both treatments were caused by the supply of feed was in accordance with the fish's needs. Feed protein content necessary to nurture silver catfish ranges from $28 \%$ - $40 \%$ (BSN, 2000), while the feed test used in this study was $31 \%-33 \%$.

Table 1. Absolute Growth and SGR of Silver Catfish

\begin{tabular}{lcc}
\hline & \multicolumn{2}{c}{ Fish growth } \\
\cline { 2 - 3 } Treatments & Absolute growth (g) & SGR (\% day) \\
\hline & & \\
A (silver catfish and lettuce) & 7.79 & 0.039 \\
B (silver catfish and water & 8.67 & 0.041 \\
spinach) & & \\
\hline
\end{tabular}

Fish growth is influenced by external and internal factors. The internal factors include age, heredity, resistance to disease, and ability to digest food while the external factors include physical properties and chemical properties of the environment, amount of food, nutritional value of available food, and the number of fish in the environment (Andriani et al., 2017). This is supported by Brett in Ogunji et al. (2008) who stated that the amount of feed that can be consumed by fish every day is one of the factors influencing optimum fish growth potential and the capacity and emptying of the stomach is closely related to the daily consumption. High protein content in feed will accelerate fish growth by increasing, especially the biomass of fish.

\section{Fish Survival}

Survival is one of the indicators of whether or not a cultivation system is feasible and is influenced by the sufficiency of food as well as by fish health and good maintenance environment (Andriani et al., 2017). Feed protein content can be used as a substance to form antibodies that fight foreign substances entering the fish (Mardhiana et al., 2017). The environmental conditions are influenced by the maintenance media hygiene factors. According to Sari et al., (2014), unuseful, and even deterimental, materials for fish will form sediment at the bottom of the maintenance container. Because of that, a nitrogen cycle occurs with the presence of decomposing bacteria and inorganic materials from food and fish metabolic wastes. Aquaponics system reduces this by absorbing the waste water using crop roots so oxidation process will start with the help of oxygen and bacteria (Dauhan et al., 2014; Zidni et al., 2019).

Based on 30 days of maintenance, the survival rate of silver catfish maintained with an aquaponics system was very good, 
with a survival rate of $89 \%(A)$ and $B(100 \%)$. This was probably caused by the ability of the maintenance media to properly met the needs of the fish. Water quality in aquaponic systems that use water water spinach was relatively better, although not significantly different from using lettuce. This related to the complexity of the root structure in both plants. The effectiveness of free ammonia absorption depends on the condition of the test plants observed, such as root conditions, number of leaves and length of plants. Water spinach plants grow faster than lettuce. This is due to the of the seeds of water spinach and its long and wide roots so that the absorption of nutrients contained in aquaculture water can be optimally absorbed. In lettuce, growth is not as fast as water spinach so that free ammonia absorption is less than optimal. However, when compared with pakcoy and red spinach, lettuce is easier to absorb nutrients because lettuce has a broad root shape. Roots are one of the important factors in determining crop productivity. The more extensive the root system, the higher the efficiency of absorption of nutrients and water by plants
(Hasan et al., 2017). Plants that have lush roots will better absorb nutrients in the water. That is because lush plants will more easily compete with plants that have less lush roots (Setijaningsih \& Gunadi, 2016).

This is because good environmental conditions from raising fish using an aquaponic system can support fish life and produce a high survival rate. This is in line with the statement of Dauhan et al.(2014), various metabolic processes that occur in the body of fish that play an important role in productivity and survival are influenced by various physical factors of water quality. In addition, Effendi et al. (2015) stated water spinach have a fast initial growth rate. These conditions support water spinach plants to grow and absorb nutrients quickly. The faster a plant grows, the more inorganic nitrogen it absorbs and the less toxic it is in aquaculture water.

\section{Stem Length of Lettuce and Water Spinach}

The average stem length of water spinach at the end of the maintenance period was around $38.7 \mathrm{~cm}$, while the length of lettuce was $20.7 \mathrm{~cm}$ which can be seen on Figure 2.

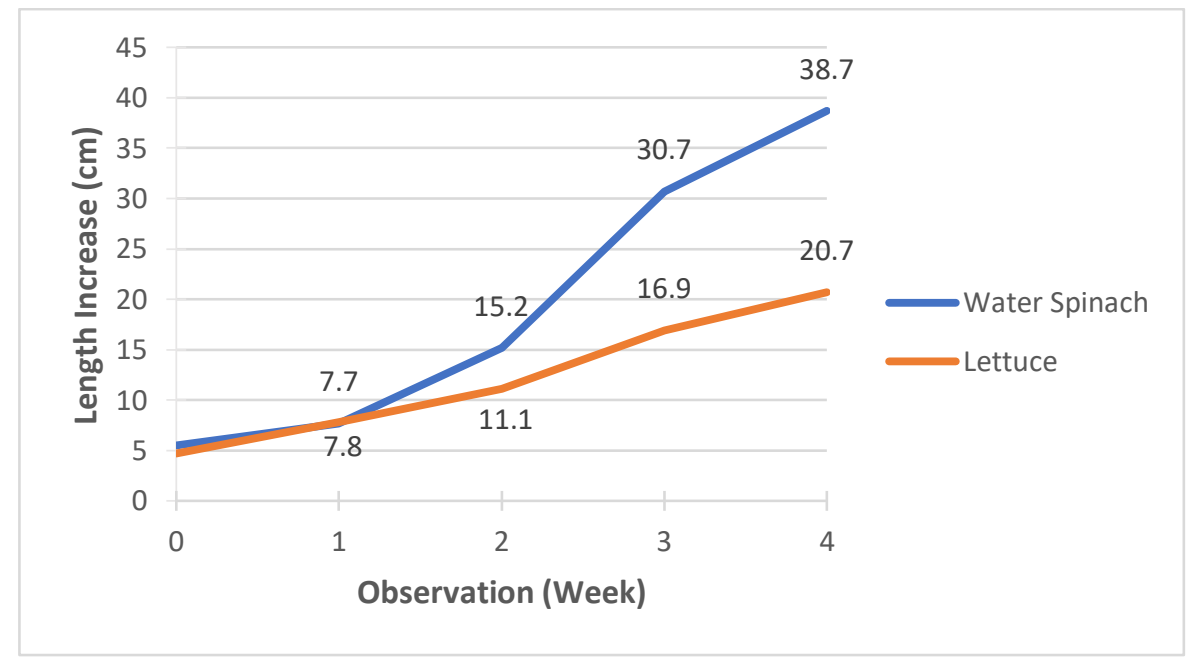

Figure 2. Increase in Crop Stem Length 
Wasonowati et al. (2013) demonstrated that crop growth is influenced by internal and external factors. The internal factors referred here relate to physiological processes. Meanwhile the external factors affecting the crop growth are solar radiation, temperature, water, and nutrient supply. The three important elements that affect stem growth are the presence of light, growth regulators, and nutrients. Water and nutrient availability affect the growth of segments, especially the cell expansion. According to Firdaus et al., (2018) nutrients and water play an important role in plant growth and development. One function of these two materials is as building material for living things. Crops that do not receive adequate light will present symptoms of etiolation, which is very fast crop growth in dark places, albeit in a weak condition with less sturdy stem (Siswadi \& Yuwono, 2015). The crop height and number of leaf increase are parallel to the increasing age of crops (Irawati \& Salamah, 2013).

\section{The Number of leaves of Lettuce and Water Spinach}

The number of leaves during this study was around 16 leaves for water spinach and 17 leaves for lettuce as shown in Figure 3. Initially the crops had an average of 4 leaves. However, after maintenance, each treatment crop had a different number of leaves. The highest number of leaves was seen in treatment with water spinach and silver catfish of 17 leaves. The number of leaves occurs due to sufficient nutrients that are made available for absorption by the crops.

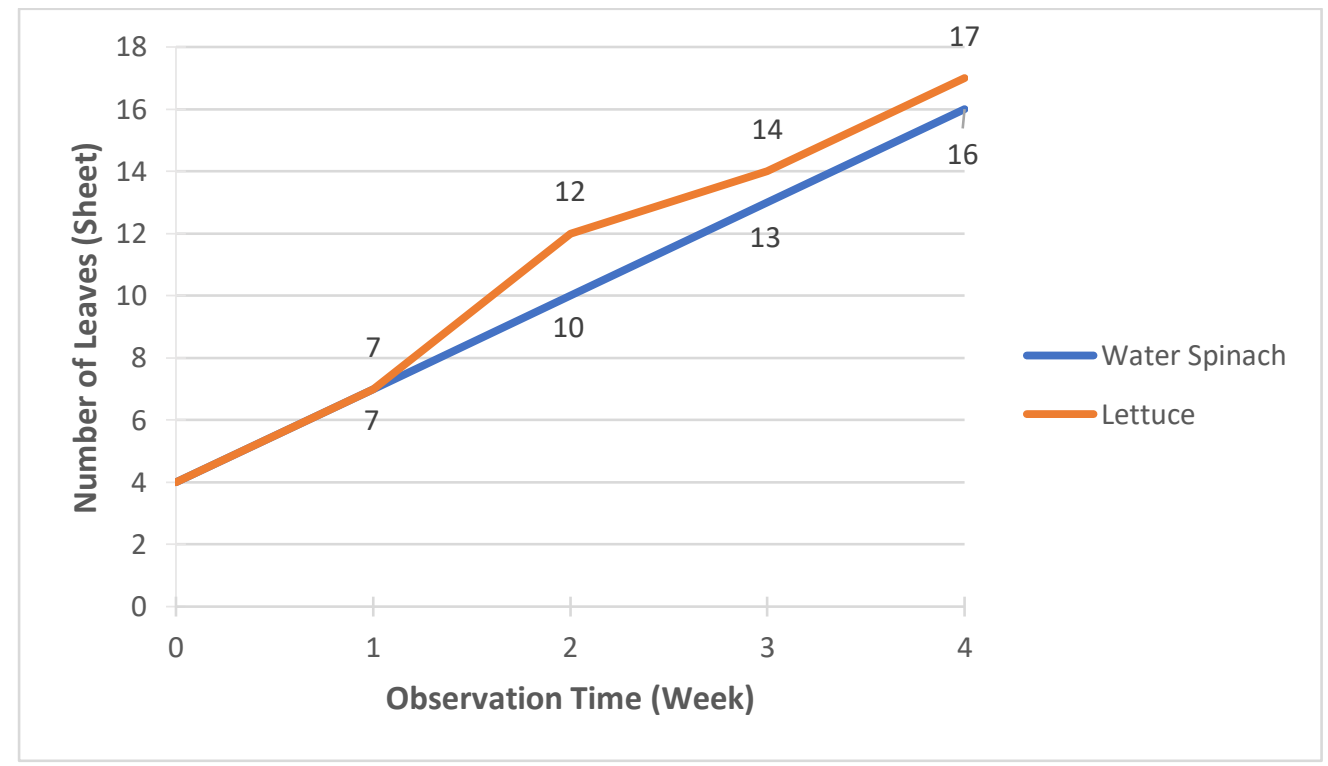

Figure 3. Number of Leaves

Leaves are vegetative organs of crops as the place where photosyntesis occurs, their number greatly affects crop growth. When crops have more leaves, the production will be greater. In addition, the number of leaves also determine photosynthesis results and affect the growth and development of the crop (Mayani et al., 2015). Crops with insufficient nitrogen will be stunted and the leaves will be smaller, 
thinner, and less in number. Meanwhile, crops that get adequate nitrogen will have a higher number of leaves formed and their size will be larger (Johnson et al., 2017).

\section{CONCLUSION}

The combination of silver catfish and water spinach crops produced the highest productivity with a final stem length of 38.7 $\mathrm{cm}$ and 16 number of leaves. This combination also generated the highest absolute growth with 7.79 grams fish $^{-1}$ and $100 \%$ survival rate. This study showed that water spinach is a more effective aquaponics system biofilter than lettuce.

\section{ACKNOWLEDGMENTS}

We would like to thank the Ministry of Research, Technology, and Higher Education of Indonesia for the PDUPT 2017 and 2018 Research Grant for support this study.

\section{REFERENCES}

Abbey, M., Anderson, N. O., Yue, C., Schermann, M., Phelps, N., Venturelli, P., \& Vickers, Z. (2019). Lettuce (Lactuca sativa) Production in Northern Latitudinal Aquaponic Growing Conditions. HortScience, 54(10), 1757-1761. https://doi.org/10.21273/HORTSCI14 088-19

Andriani, Y., Dhahiyat, Y., Zahidah, \& Zidni, I. (2017). The effect of stocking density ratio of fish on water plant productivity in aquaponics culture system. Nusantara Bioscience, 9(1), 31-35.

https://doi.org/10.13057/nusbiosci/n 090106

Andriani, Y., Zahidah, Yustiati, A., Junianto,
Iskandar, \& Harditama, E. (2019). Productivity of Various Plant in Aquaponics Systems. Global Scientific Journals, 7(11), 1321-1338.

BSN. (2000). Benih Ikan Lele Dumbo (Clarias gariepinus $\mathrm{x}$ C.fuscus) Kelas Benih Sebar. Sni : 01-6484.2-2000.

Damanik, B. H., Hamdani, H., Riyanti, I., \& Herawati, H. (2018). Uji Efektivitas Bio Filter Dengan Tanaman Air Untuk Memperbaiki Kualitas Air Pada Sistem Akuaponik Ikan Lele Sangkuriang (Clarias gariepinus). Jurnal Perikanan Dan Kelautan, IX(1), 134-142.

Dauhan, R. E. S., Efendi, E., \& Suparmono. (2014). Efektifitas Sistem Akuaponik Dalam Mereduksi Konsentrasi Amonia Pada Sistem Budidaya Ikan. E-Jurnal Rekayasa Dan Teknologi Budidaya Perairan, III(1), 297-302.

Effendi, H., Amalrullah Utomo, B., Maruto Darmawangsa, G., \& Elfida Karo-Karo, R. (2015). FitoremediasI limbah budidaya ikan lele (Clarias sp.) dengan kangkung (Ipomoea aquatica) dan pakcoy (Brassica rapa chinensis) dalam sistem resirkulasi. Jurnal Ecolab, 9(2), 80-92. https://doi.org/10.20886/jklh.2015.9. 2.80-92

Effendie, M. I. (1979). Biologi Perikanan. In Yayasan Pustaka Nusatama Yogyakarta.

Firdaus, M. R., Hasan, Z., Gumilar, I., \& Subhan, U. (2018). Efektivitas Berbagai Media Tanam Untuk Mengurangi Karbon Organik Total Pada Sistem Akuaponik Dengan Tanaman Selada. Jurnal Perikanan Dan Kelautan Vol., IX(1), 35-48.

Gaspersz, V. (1995). Teknik analisis dalam penelitian percobaan. In Tarsitom. https://doi.org/10.21098/bemp.v15i1 
Hasan, Z., Andriani, Y., Sahidin, A., \& Rubiansyah, M. R. (2017). Pertumbuhan tiga jenis ikan dan kangkung darat (Ipomea reptans Poir) yang dipelihara dengan sistem akuaponik. Jurnal Ikhtiologi Indonesia, 17(2), 175-180.

Irawati, I., \& Salamah, Z. (2013). Pertumbuhan Tanaman Kangkung Darat (Ipomoea reptans Poir.) Dengan Pemberian Pupuk Organik Berbahan Dasar Pupuk Kelinci. Jurnal Bioedukatika, 1(1), 3-14. https://doi.org/10.26555/bioedukatik a.v1i1.4079

Johnson, G. E., Buzby, K. M., Semmens, K. J., Holaskova, I., \& Waterland, N. L. (2017). Evaluation of Lettuce Between Spring Water, Hydroponic, and Flowthrough Aquaponic Systems. International Journal of Vegetable Science, 23(5), 456-470. https://doi.org/10.1080/19315260.20 17.1319888

Kamauddin, M. J., Ali Ottoman, N. S. I., Abu Bakar, M. H., Johari, A., \& Hassim, M. H. (2019). Performance of Water Treatment Techniques on Cocopeat Media Filled Grow Bed Aquaponics System. E3S Web of Conferences, 90, 1-10.

https://doi.org/10.1051/e3sconf/201 99002001

Mardhiana, A., Buwono, I. D., Andriani, Y., \& Iskandar. (2017). Suplementasi Probiotik Komersil Pada Pakan Buatan untuk Induksi Pertumbuhan Ikan Lele Sangkuriang (Clarias gariepinus). Perikanan Dan Kelautan, VIII(2), 133139.

Mayani, N., Kurniawan, T., \& Marlina. (2015). ( Ipomea reptans Poir ) Akibat Perbedaan Dosis Kompos Jerami
Vol., 15(13), 201559-201563.

Ogunji, J., Summan Toor, R. U. A., Schulz, C., \& Kloas, W. (2008). Growth performance, nutrient utilization of Nile tilapia Oreochromis niloticus fed housefly maggot meal (magmeal) diets. Turkish Journal of Fisheries and Aquatic Sciences, 147(1), 141-147.

Ramadhan, A., Suwandi, R., \& Trilaksani, W. (2016). Competitiveveness Strategies of Indonesia Pangasius Fillet. Indonesian Journal of Business and Entrepreneurship, 2(2), 82-92. https://doi.org/10.17358/ijbe.2.2.82

Rokhmah, N. A., Soraya Ammatillah, C., \& Sastro, Y. (2014). Vertiminaponik, Mini Akuaponik untuk Lahan Sempit di Perkotaan. Buletin Pertanian Perkotaan, 4(30), 14. http://jakarta.litbang.pertanian.go.id/ ind/artikel bptp/buletin vertiminaponik vol4 no.2 2014.pdf

Sari, M., Hatta, M., \& Permana, A. (2014). Acta Aquatica. Acta Aquatica, 1(1), 24-30.

Setijaningsih, L., \& Gunadi, B. (2016). Efektivitas Substrat Dan Tumbuhan Air Untuk Penyerapan Hara Nitrogen Dan Total Fosfat Pada Budidaya Ikan Berbasis Sistem Integrated MultiTrophic Aquaculture (Imta) Prosiding Forum Inovasi Teknologi Akuakultur 2016, October.

Siswadi, \& Yuwono, T. (2015). Pengaruh Macam Media Terhadap Pertumbuhan Dan Hasil Selada ( Lactuca sativa L) Hidroponik. Jurnal Agronomika, 09(03), 257-264. http://download.portalgaruda.org/art icle. php?article $=296580 \& v a l=5171 \&$ ti tle=PENGARUH

Thong, N. T., Ankamah-Yeboah, I., 
Bronnmann, J., Nielsen, M., Roth, E., \& Schulze-Ehlers, B. (2020). Price transmission in the pangasius value chain from Vietnam to Germany. Aquaculture Reports, 16(December 2019), 100266.

https://doi.org/10.1016/j.aqrep.2019. 100266

Wasonowati, C., Suryawati, S., \& Rahmawati, A. (2013). Respon Dua Varietas Tanaman Selada (Lactuca sativa L.) Terhadap Macam Nutrisi Pada Sistem Hidroponik. Agrivor, 6(1), 50-56.

http://kompetensi.trunojoyo.ac.id/ag rovigor/article/viewFile/1478/1265

Wongkiew, S., Hu, Z., Chandran, K., Lee, J. W., \& Khanal, S. K. (2017). Nitrogen transformations in aquaponic systems: A review. Aquacultural
Engineering, 76, 9-19. https://doi.org/10.1016/j.aquaeng.20 17.01.004

Yep, B., \& Zheng, Y. (2019). Aquaponic trends and challenges - A review. Journal of Cleaner Production, 228, 1586-1599.

https://doi.org/10.1016/j.jclepro.201 9.04.290

Zidni, I., . I., Buwono, I. D., \& Mahargyani, B. P. (2019). Water Quality in the Cultivation of Catfish (Clarias gariepinus) and Nile Tilapia (Oreochromis niloticus) in the Aquaponic Biofloc System. Asian Journal of Fisheries and Aquatic Research, 4(April), 1-6. https://doi.org/10.9734/ajfar/2019/v $4 \mathrm{i} 230048$ 